\title{
Forged Aluminum Pot Production as a Vocation and Its Economic Impetus
}

\author{
Oke A. Gabriel \\ Fine and Applied Art Department \\ Umar Suleiman College of Education, Gashua \\ Yobe State-Nigeria \\ Oyeniyi A. Yames \\ Economics Department, \\ Umar Suleiman College of Education Gashua, \\ Yobe State-Nigeria
}

\section{Doi:10.5901/mjss.2013.v4n12p61}

\begin{abstract}
There are thousands of graduates today along the street looking for works to do in other to earn their livings. There are also lots of vocational works at the local ends which people can pick up and do. One of such is aluminum pot forge production. But people look down on it as invaluable work. This paper therefore intends to enumerate aluminum pot forge production as a good aspect of vocational education for self-reliance. It also traces the availability of materials, studio set up, tools and equipments as well as production processes. The economic impetus to the youths especially the unemployed is however explained. More so, the role of vocational art teacher in introducing the forging method of producing Aluminum pot to students in tertiary institutions is included.
\end{abstract}

\section{Introduction}

Oke (2004) said, any economists, sociologists and development analysts have traced reasons for the unfortunate state of economic and technological backwardness of societies in African countries the cause is the low level of technology and lack of political will by our leaders to develop the existing local technology we have. Vocational work is a thing of necessity in a developing country like Nigeria. The aspiration of our leaders in the government and the people in this country should be to use our present system of education to fight unemployment, economic recession and shortage of skilled manpower in this present dispensation this should be done through vocational education. There are lots of vocational works which the people can develop as local technologies to standard. One of such local technologies is aluminum pot production through forging method. Training in vocational education will make the people creators, efficient producers and creative consumers and not mere parasitic consumers. Such person will be proud of been self-reliant.

\section{Forged Aluminum Pot as a Vocation}

Horby (2005) said that vocation is a type of work or way of life that is believed to be especially suitable for life. This requires skill and knowledge which the person need to process in other to do a particular work. The qualification and training needed to acquire the skill is referred to as vocational education. Wikipedia (2012) refers to vocational education as an education that prepares people for specific trade, craft and carrier at various levels. Suleiman (2012) said that aluminum pot is one of the locally practiced art work which fetch daily bread to people at the grass root in terms of production and use. 
The production of aluminum pot takes place in every locality throughout Nigeria. The rate and extent at which it takes place may vary. As for Bade local government, it is practiced in almost every town. But the people involved in the production are uneducated there is increasing demand for aluminum pot because of durability. Bassey (2004) said that aluminum cook wares have reduced the demand for traditional pots. Okunna (2004) also testified to the last statement by saying that there is also demand for aluminum cooking pot instead of clay pot. This means that there is increasing demand for aluminum pot in the market.

\section{The Potter and the Studio}

The people involved in this aluminum pot production are mostly uneducated, probably primary or secondary school leaver. They only went to learn the craft in a studio set up. The studio is always in thatched form. Apprenticeship does not require long time. The studio usually includes major sections like would making, casting and melting sections. Others are materials and equipment/tools sections. The studio does not require much money to set up.

\section{Materials}

Aluminum is a popular material for cookware quite durable and excellent conductor of heat kitchens (2013). It is comparatively low cost material which is gradually replacing clay pot at the grass root in Nigeria. Recycling method is adopted in supplying raw material. The pot makers depend on aluminum products that have been use and thrown away. They engage the small children like "almajiris" to gather used aluminum products from the streets, gutters and dust bins. These are broken spoons plates, old aluminum pots, cocacola cans and other containers. Abubakar (2011) said that the pothers also visit mechanic workshops, bicycle repairers and iron benders for getting used aluminum part of generator and motorcycle.

\section{Tools and Equipments}

The major equipment used are:- air blowing machine, wheel, fire mouth, iron pot (old gas container of refrigerator). These are used in the melting section. Sliced aluminum pot and wooden guide are the main equipments used when making the world of the pot. A bucket of water is also needed during casting. These equipments are locally constructed by the blacksmiths and carpenters. The tools are pincers, hammer, metal rods, wooden rods and knives.

\section{Production Process}

The process requires the effort of two or more people. The blowing machine is permanently connected to fire mouth with a pipe. chacoal is used to fire the aluminum material inside the iron pot on top of the fire month. One person gradually gears the blowing machine that blows air to the fire mouth. The material melt to liquid form. One or two pieces of dry cell battery (used for touch light) are added to it. This enables the impure materials to float and removed from the pot. Before the melting process complete, the mold must have been prepared. A sliced aluminum pot is banded with wire and tilled tightly with moisture clay. This is turned upside down on a smooth plain ground. Clay is firmly stuck round the pot. Marks is made to run through the joint of the two would in other not to miss the replacement. This is done half way before a second wooden guide is placed on top and the same process is repented as above. Thereafter the sliced pot is technically removed from the mold. Many of such mold should be prepared as much as required before casting. 


\section{Casting Stage}

As soon as the hot solution is ready, a metal pincer is used to remove the pot from the sire and pure the liquid into the mold through a hole on top. The cast is allowed to cool down for at least five minutes before the aluminum rot is removed pot is removed from clay mold. A metal file is finally used to run through the body of the pot in finishing order.

\section{Prospects}

Aluminum pot forge has bright future judging from the fact that demands for product is always higher than supply every day. The potters have never complain of no market for the production this is simply because of the demand as explained by the academic clay potters. Besides this prior advantage, there are other products. There are other products that can be produced apart from pot. Fry pans, cups, bowls, flat plates and spoons are easily produced for local use. Handles of knives and cutlasses as well as defected pots can be mended. Many more shapes and forms of objects can be derived out if properly handled by intellectuals.

\section{Economic Impetus}

CBN (2012) alerted that the unemployment rate in Nigeria is 47\% especially the youths excluding the present graduates in the youth service who will all depend on white collar job that is not forth coming. Hence, to achieve the objectives of the educational system and be just, equalitarian and self-reliant nation (Nigeria national policy on education 2004), there is need for adequate attention to be accorded to vocation education in which aluminum pot production is an aspect.

It is discovered that aluminum potters are literate enough and are assisted, will boost the production and further generate employment opportunity. In this regard, the following importance can be derived from aluminum pot production.

1. Cost: This refers to the total amount of money that is needed in establishing and running the business. This is observed in three ways:-

a. Cost of studio set up: The setting up the studio for aluminum pot production requires little amount of money. The capitals needed are a small portion of land for the construction of the studio. Local blacksmiths and carpenters can be contacted for the constructions of equipments and tools at very cheap rate.

b. Source and cost of raw materials. The mechanics and repairers can be contacted for the supply of west aluminum products at low cost some can be freely got from dung hill and along the streets. This idea thereby enables the supply of raw material at cheap cost.

c. Cost of production: it is the cost of production and transportation that actually make the imported aluminum cook wares very costly in Nigeria. Despite the fact that the imported cook waves have thin walls which may not last long in African local use. The locally produced pot is thicker, stronger and conducive to local use. The low cost of production and little or no cost of transportation of the locally produced pot is an advantage over the imported ones.

2. Demand and supply: the steady supply of locally produced pot at low cost will meet increasing demand by the Nigerians. This will equally make it possible for exportation to neighbouring countries in Africa.

3. Employment generation: The above opportunities derivable from locally produced pot visibly give room for self-employment and employment of other people. As people engage in production, some other people are engaged in wholesale and retail aspect of marketing the products. More so, some other firms rise up to render services to the industry. People will also engage themselves in research and development. 
4. Good source of Revenue: This can only be made possible if adequate attention is given to the production. This will require setting it up as a standard local industry though modern technology, proper funding for commercial purpose. Revenue can be generated by the local, state and federal governments.

5. Standardization of local industry: Well trained educators and technologist would make further research on innovations of new machine, techniques and methods of production. Marketing strategy at both national and international levels will also be searched out. This will enable it compete with other international cookware industries of the world.

\section{The Role of the Teacher}

The teacher is the immediate intellectual self that should link the student with the aluminum pot forge through the theory and practical method of production. The teacher should look at it as a career work that can solve economic problems. The teacher should look for means of advising the government at local, state or federal levels to encourage loan to people for establishment. He should also take up the responsibly to search for how to solve immediate and future problems of Forge Aluminum pot as a vocation. These include the marketing strategy and competition with other similar production. The teacher should also search for some other vocations that have brighter future to bring to the knowledge of the students. He is also the intermediary between the government and the student to give the best advice to both the government and the students concerning the way out.

\section{The Roles of the Government}

The government should not tarry to grab this opportunity to solve part of unemployment problem by offering the following responsibilities.

- Include aluminum pot production in the tertiary institutions curriculum in the aspect of vocational education.

- Establish vocational training institutes where aluminum pot making can be practiced and training people.

- Sponsor vocational education teachers for research and development on aluminum pot production. This includes modernization of tools and equipments.

- Give loan to people for the establishment of studio and local industries.

- Popularize aluminum pot making through public advertisement and encourage the trainees, the trained and the trainers.

\section{Conclusion}

It is worthy to know that aluminum pot production has bright future as one of the solution to self-employment in this country. This should come across everybody's mind that for a successful future to be guaranteed in this computer age, there must be cognizance that will bring revival into self-employment trade like this. This cannot be possible except through vocational education this will not allow posterity to tell on our negligence.

\section{References}

Abubakar H. (2011) Problems and prospects of improvisation of Aluminum pot in Potiskum Area of Yobe State, Unpublished Project for the award of NCE Certificate, Fine and applied Art Department Umar Suleiman College of Education Gashu'a, Yobe State.

Bassey E.A (2004): Ibiobio Pottry Heritage: A focus on Ndom Ebom Pottery. Nigeria Crafts and Techniques. Nigeria Cat forum. Department of Industrial Design FUTA, Akure 
Horby (2005): Oxford Advanced Learners' Dictionary. International Students. Edition, Oxford University Press. Oxford. H.Y.

Okee (2001) Ceremic Vocation for Technological and Educational Development in Nigeria with Particular reference to Yobe State Oasis a multidisciplinary Journal of Education. A Publication of the Academic Staffs, College of Education, Gashu'a Yobe State.

Okunna (2004): Traditional Pottery Practice in Contemporary Nigeria. Nigeria Craft and Technique Nigeria Craft Forum. Industrial Design Programme FUTA Akure.

Suleiman M. (2011): Improvisation of Equipment for Aluminum pot Production in Fine and Applied Art Umar Suleiman College of Education Gashu'a. Unpublished project for the award of NCE Certificate.

Kichens www.kichenscookshop.co.uk/shop/ite.july22.

C.B.N (2012) Bulletin on Economic Growth and Development.

Federal Government of Nigeria (2004) National Policy on Education (Revised edition) 
